\title{
REFORMA, REVISÃO E EMENDA CONSTITUCIONAL, NO DIREITO BRASILEIRO
}

\author{
MANOEL GonÇALVES FERREIRA FILHO*
}

\begin{abstract}
I. Preliminares. II. Poder Constituinte originário e Poder Constituinte derivado. III. O Poder de alterar a Constituição. IV. A alteração da Constituição segundo a Lei Magna de 1988. V. O controle de constitucionalidade da alteração constitucional. VI. Conclusão.
\end{abstract}

\section{Preliminares}

\section{Colocação do tema}

A questão, ou melhor, as questões postas como tema deste trabalho envolvem problemas extremamente delicados e controvertidos do direito constitucional e certamente tocam pontos sensíveis da própria filosofia e teoria geral do direito.

Com efeito, não é possível, sem incidir em precipitação condenável que tiraria todo valor ao estudo, examinar a possibilidade do controle de constitucionalidade das alterações constitucionais - a reforma, revisão ou emenda - sem remontar aos próprios fundamentos da Constituição. Isto reclama o exame, ainda que resumido, da doutrina do Poder Constituinte.

Não basta, porém, fazê-lo. É mister ir além e estudar a natureza do Poder de alterar a Constituição, pois somente assim se inferem as premissas da resposta ao tema proposto.

Estas duas observações justificam o plano que vai ser seguido. Primeiro, a recordação das linhas mestras da contraposição entre Poder de originar a Constituição - Poder Constituinte originário - e Poder de modificar a Constituição, habitualmente designado com Poder Constituinte derivado.

* Professor Titular de Direito Constitucional da Faculdade de Direito da USP. Doutor honoris causa da Universidade de Lisboa. Doutor pela Universidade de Paris. Ex-professor visitante da Faculdade de Direito de Aix-en-Provence (França). Membro da Comissão Executiva da Association Internationale de Droit Constitutionnel - AIDC. Presidente do Instituto "Pimenta Bueno" Associação Brasileira dos Constitucionalistas.

R. Dir. Adm.,

Rio de Janeiro, 223: 53-74,

jan./mar. 2001 
Depois disto - visto ser o direito brasileiro o alvo das indagações - cumpre estudar a modificação da Lei Maior conforme as regras estabelecidas pela Constituição em vigor. E também, assunto pouco estudado, o controle de constitucionalidade sobre as alterações constitucionais.

\section{Nota terminológica}

É necessário, todavia, de pronto formular uma observação terminológica.

De fato, não faltam eminentes juristas que, com erudição e rigor, pretendem haver uma terminologia cientificamente precisa a respeito dos modos de alteração, ou mudança da Constituição de acordo com a Constituição. Reforma seria sempre uma alteração que abranja o texto todo - mal comparando como a Emenda $n^{\circ} 1 / 69$ o foi para a Constituição de 1967. Revisão seria sinônimo de reforma, mas principalmente quando periodicamente programada. Já a emenda seria apenas a alteração pontual do texto constitucional. Admita-se que, pela lógica e pela linguagem, assim seja. Entretanto, não é esta a prática na doutrina, nem há razão para impô-la dogmaticamente.

Souza Sampaio, que escreveu com maestria sobre o assunto, intitulou o seu livro de $O$ poder de reforma constitucional ${ }^{1}$ e nele trata largamente da emenda... Eu, candidamente, no trabalho o Poder Constituinte ${ }^{2}$, elaborado em 1973, para o qual reivindico o mérito de introduzir a discussão no Brasil da doutrina de Sieyès (que até então não era sequer citado pelos eruditos), chamei de Poder de Revisão o poder de modifica a Constituição de acordo com a Constituição. É o que fazem os portugueses, como Jorge Miranda, como Canotilho. Estes que conhecem a língua, sabem que o termo emenda pode assumir um sentido pejorativo de remendo ou correção... No estrangeiro, os franceses nunca falam em amendement, mas sempre révision. São os americanos que dizem amendment.

Por outro lado, o nosso direito constitucional positivo jamais teve uma precisão de linguagem a esse respeito.

A Carta do Império, no art. 174 falava em reforma. Igualmente, a Constituição de 1891, no art. 90, previa também reforma, contudo, em 1926, promulgaram-se emendas a ela.

A Constituição de 1934 distinguia revisão de emenda, prevendo procedimento diferente para cada uma das espécies. Entretanto, quem consultar o seu art. 178, verá que revisão concernia não ao reexame global do texto mas à alteração de matérias determinadas, que formam o cerne político da Lei Magna, enquanto emenda seria a alteração de outros pontos, menos importantes, da mesma.

A Carta de 1937, esta não quis comprometer-se. Sob o título Das Emendas à Constituição, estipula, no art. 174 que "a Constituição pode ser emendada, modificada ou reformada por iniciativa do Presidente da República ou da Câmara dos Deputados".

1 Salvador, 1954.

2 Cuja $1^{\text {a }}$ edição é de 1974. (Hoje, em $3^{\text {a }}$ ed., Saraiva, São Paulo, 1999. 
A Constituição de 1946 (art. 217), a de 1967 (art. 49, I), a Emenda n 1/69 (art. 46, I) somente falaram em emenda.

A de 1988, esta sim, distingue emenda (art. 60) da revisão, ou melhor, da revisão prevista (e realizada) cinco anos depois de sua promulgação (A.D.C.T., art. $3^{\circ}$ ). Mas, durante esta, promulgaram-se emendas..., batizadas de Emendas de revisão.

A dedução de tudo isto é inexistir uma terminologia fixada sobre o assunto. Ou todos os autores e legisladores citados estarão errados e somente certos alguns eruditos?

Ademais, será que, emendando uma Constituição, não se estará revendo o seu texto, ou procedendo à reforma deste? Ou quando se reforma ou revê este texto não se estará a emendá-lo?

\section{Poder Constituinte originário e Poder Constituinte derivado}

\section{A contraposição usual}

Para a doutrina clássica ${ }^{3}$, existe um Poder que dá origem à Constituição, por isso, Poder Constituinte originário e um Poder que pode alterar essa Constituição - o Poder de Revisão ${ }^{4}$ que deriva do primeiro, exatamente por intermédio da Constituição, por isso Poder Constituinte derivado ${ }^{5}$.

\section{a) A doutrina clássica do Poder Constituinte}

\section{A origem da doutrina}

É bem conhecido ter sido a idéia de Poder Constituinte formulado pelo Pe. Emmanuel Joseph Sieyès ${ }^{6}$, às vésperas da Revolução Francesa, num panfleto intitulado Qu'est-ce que le Tiers État??

$\mathrm{Na}$ verdade, neste livro, Sieyès preocupa-se com a necessidade de igualizar o terceiro estado, o povo, aos dois outros, os estados privilegiados, clero e nobreza, quanto a direitos e obrigações. Ora, isto passava, na época, por uma modificação do que já se chamava de constituição - o conjunto de leis fundamentais que regiam um Estado - na linguagem moderna, o conceito material de Constituição.

3 Talvez mais exatamente doutrina comum...

4 Como teimo em chamá-lo.

5 Vale observar que o Poder de Revisão não é o único Poder Constituinte derivado da Constituição. O que institucionaliza, no federalismo por segregação, os Estados-membros de um Estado federal também o é. V. a este respeito meu o Poder Constituinte, cit., p. 141 e s.

6 Como sempre acontece, já se apontou quem o tenha precedido. No caso, um ilustre, mas desconhecido, americano, cuja manifestação passou desapercebida e não teve, em consequiência, qualquer influência. Trata-se de um Thomas Young que, em 1777, na Pensilvânia, falou em constituent power ou supreme constituent power, por oposição e supreme delegated power. Cf. Claude Klein, Théorie et pratique du Pouvoir Constituant, P.U.F., Paris, 1996, p. 13.

7 V. cap. V. 
Para demonstrar ser isto possível, formula a tese de que existe um Poder Constituinte que institucionaliza o Estado. Poder este que pertence ao povo, ou nação, Poder este que pode sempre voltar a manifestar-se porque não se esgota em qualquer das suas obras. (Portanto, poderia refazer a constituição francesa, estabelecendo a igualdade desejada).

Desdobrando o tema, a fim de dar maior força à colocação, remonta à hipótese do estado de natureza - em que os homens viveriam livres, usando de seus direitos naturais - que o estado social, decorrente de um pacto livremente acordado entre os seres humanos, substituiria - pacto este que estabeleceria a limitação, não a perda, dos direitos fundamentais. Criada pelo pacto a sociedade, como é preciso, para garanti-la, a existência de um Poder, um comando, os homens associados elegeriam representantes extraordinários, os quais estabeleceriam a Constituição, isto é, o estatuto do Poder político. Representantes ditos extraordinários para enfatizar não serem os próprios representantes ordinários que exerceriam, de acordo com a Constituição, o poder instituído.

Mas se este seria o modo normal de edição da Constituição - assembléia constituinte de representantes especiais - o Poder Constituinte não estaria adstrito a esse proceder, poderia manifestar-se de modo ou forma que quisesse. (Portanto, também na assembléia dos Estados Gerais, convocada por Luíz XVI, a reunir-se em 1799).

Estão aí definidos os pontos básicos da doutrina clássica. São eles para muitos, ainda hoje, dogmas do direito constitucional.

\section{Os caracteres do Poder Constituinte}

Dessas idéias extraiu a doutrina clássica os caracteres do Poder Constituinte.

O primeiro deles é inicialidade. É ele quem funda a ordem jurídica, instituindo a sua base, a Constituição. Assim, sua força não provém do direito anterior, mas se afirma por autoridade própria.

Toda a ordem jurídica, portanto, deve ser concebida como procedente da Constituição. Isto importa logicamente na perda da eficácia de ordem jurídica anterior eventualmente existente. Esta, porém, pode ser objeto de recepção pela (nova) Constituição, desde que compatível com esta, voltando a ter eficácia. Mas sua força tem de ser considerada como fruto da Constituição que a recebe. Conseqüentemente, todas as normas de uma ordem jurídica anterior que não são compatíveis com a nova Constituição perdem com a vigência desta a sua eficácia e não a recobram ${ }^{8}$.

O segundo traço é a ilimitação. Sendo inicial, o Poder Constituinte não encontra limites de direito. É juridicamente ilimitado. Ou soberano, como se usa dizer. Mas, aqui, duas correntes se formam. Uma, jusnaturalista, a que pertencia o próprio Sieyès, entende que a ilimitação existe mas em face do direito positivo - o que é óbvio não perante o direito natural. Este limitaria o Poder Constituinte. Outra, positivista, evidentemente recusa qualquer limite, conquanto uma ala moderna veja esse Poder limitado pelo direito internacional. 
O terceiro traço é mera decorrência da ilimitação. Não está ele adstrito a forma alguma. É incondicionado. Manifesta-se como quiser ${ }^{9}$.

A estes três características é que se reconheceria o Poder Constituinte.

\section{Crítica dessa doutrina}

A tese clássica é logicamente sedutora, mas absolutamente irrealista. Trata-se de um mito, diz Claude Klein ${ }^{10}$.

É preciso enxergar muito além da realidade, para ver nos que elaboram uma Constituição, depois de uma revolução - e este é o caso que mais se aproxima do modelo - representantes do povo investidos de um poder extraordinário, diferente do que, mais tarde, recebem do mesmo povo os que este elege para que governam de acordo com a Constituição que for estabelecida. Existe, nas duas situações, uma atribuição de decidir pelo povo-eleitor, não mais, nem menos. Ou seja, uma relação de representação-imputação - o representante "quer" pelo representado, a quem se imputa a vontade enunciada" ${ }^{\prime \prime}$.

É verdade que, quando os eleitos o são exclusivamente para estabelecer uma Constituição, ainda se pode dizer que foram escolhidos para uma missão diversa da ordinária, qual seja a de estabelecer a Lei fundamental. Mas isto é raro na história. E a diferença encontrada situa-se na finalidade, não na natureza da relação com o povo.

Sem dúvida, mais de perto da teoria se chega quando o povo ratifica num referendo a Constituição. Ainda assim ele não a elabora, salvo em ficção.

Por outro lado, embora a incondicionalidade cubra tudo, muito difícil é ver no Poder Legislativo de um Estado que é investigado do poder de estabelecer uma nova Constituição, um Poder Constituinte, ainda que seja ele declarado pleonasticamente livre e soberano. Nem se fale nos casos em que é órgão de um Estado - como o Parlamento britânico em relação a numerosas colônias que acediam à independência - que edita a Constituição ${ }^{12}$.

O mérito da doutrina clássica é dar uma explicação atraente e lógica para a supremacia da Constituição. Especialmente para justificar sejam os governantes sujeitos à Constituição $\mathrm{e}$, por isso, obrigados nos seus atos a obedecer a uma condição de constitucionalidade. E sob pena de invalidade de tais atos.

\section{b) A visão decisionista}

\section{A doutrina de Carl Schmitt}

A doutrina tradicional foi de certa forma modernizada por Carl Schmitt. Claro

9 O que torna a teoria útil aos autores de golpe de Estado que invocam o incondicionamento para promulgar a Constituição que desejam e os legitimem. É o que fez Getúlio Vargas, em 1937.

10 p. 194.

11 Juridicamente é isto a representação. Politicamente pode haver - pode, sublinhe-se - a expressão pelo representante de um querer preexistente do representado, mas isto é muito raro.

12 V. meu livro Estado de Direito e Constituição, Saraiva, São Paulo, $2^{*}$ ed., 1999, p. 105 e s. 
está que não parte ele do estado de natureza. Entretanto, sua posição não rompe com a idéia de que existe um Poder Constituinte, o qual se manifesta, estabelecendo uma Constituição.

Aponta o mestre alemão que toda Constituição consiste numa "decisão de conjunto sobre o modo e forma da unidade política" desejada por uma comunidade ${ }^{13}$. Ora, surge a Constituição "mediante um ato do Poder Constituinte".

$\mathrm{Na}$ verdade, a Constituição propriamente dita - a Constituição em sentido positivo - resumir-se-ia aos princípios e regras que exprimiriam tal decisão, as quais seriam desdobradas por simples normas constitucionais - Constituição em sentido relativo. Daí a distinção para sua obra entre Constituição (positiva) e meras leis constitucionais (Constituição relativa).

Dessa tese extrai ele inúmeras consequiências importantes para a visão moderna do Poder Constituinte, como a idéia de núcleo intangível (imutável e insuscetível de modificação por emenda), a de fraude à Constituição (a adoção de regras que colidam com o referido núcleo etc.).

\section{A "idéia de direito" e os limites do Poder Constituinte}

Observe-se, associando à tese de Schmitt a lição de Burdeau ${ }^{14}$, que cada manifestação do Poder Constituinte traduz uma "idéia de direito". Ou seja, a decisão formula a opção por uma concepção do justo em matéria política (e social). Ou declara uma nova idéia, ou confirma uma já consagrada, mas para reiterá-la quando deturpada ou corrompida.

Esta idéia seria o limite político do agente (assembléia, ou grupo, ou mesmo indivíduo) que exprime o Poder Constituinte do povo. Sim, porque, se o titular deste Poder é a comunidade, jamais é ela inteira, salvo por representação, que o exerce.

\section{O núcleo essencial da Constituição}

Ora, o cerne fundamental de uma Constituição, esteja ele explícito ou não no texto, é exatamente a condensação dessa idéia de direito.

Tal idéia é a fonte da legitimidade do Poder Constituinte e conseqüentemente da própria Constituição ${ }^{15}$.

Ora, esta legitimidade justifica a revolução, instrumento por que o Poder Constituinte o mais das vezes triunfa ${ }^{16}$.

13 Teoria de la Constitución, trad. esp., México, s/data, p. 23 e s.

14 V. Burdeau Georges, Tratté de Science Politique, tomo I - Le Pouvoir Politique, Paris, Librairie Générale, 1949, p. 92 e s.

15 V. meu $O$ Poder Constituinte, ob. cit., p. 47 e s.

16 V. Cattaneo Mario A., Il concetto di Rivoluzione nella Scienza del Diritto, Ed. Cisalpino, Milão, 1960. 


\section{Mudanças informais e modificação formal da Constituição}

A aplicação da Constituição inexoravelmente a modifica, na medida em que a conforma a pressões e inovações ${ }^{17}$.

Neste passo, salta aos olhos o papel do Judiciário, mormente das Cortes constitucionais. Estas, como intérpretes das normas editadas na Lei Magna, sempre acabam por lhes alterar o sentido e o alcance. Traz isto aspectos positivos, pois serve para adaptar as regras a tempos novos, para construir soluções desconhecidas pelo legislador constituinte. Essa interpretação construtiva é um dos méritos históricos da Suprema Corte dos Estados Unidos. Sem dúvida, é um dos títulos da Corte Constitucional alemã, a que mais fez progredir, nestes últimos decênios, o direito constitucional.

Estas alterações, porém, são informais, visto que não importam em mudança do texto, mas do sentido do texto. Este formalmente continua o mesmo.

Nem sempre isto ocorre, todavia, e nem sempre é possível.

\section{a) A modificação formal da Constituição}

\section{A necessidade de alterar a Constituição}

Com efeito, uma vez estabelecida a Constituição pode ser conveniente alterá-la. Com a obra humana é sempre imperfeita, como o mundo evolui, A Lei suprema não pode ser editada de uma vez para todo o futuro. Põe-se então a questão de sua alteração, seja or supressão de disposições, seja por modificações no texto, seja por adições a este. É esta, em particular, a sina das constituições enxundiosas, ditas analíticas, como a Brasileira em vigor, que, detalhando soluções, logo se tornam inadequadas em face de novos tempos ou de novas políticas.

Claro está que, seguindo-se a doutrina clássica, a qualquer momento o Poder Constituinte pode manifestar-se, mas editando nova Constituição. Tal situação traz o inconveniente de importar numa quebra da ordem jurídica, o que não é desejável. Sim, porque este rompimento é visto pela teoria como revolução ${ }^{18}$.

Para evitar este recurso extremo, prevêem as Constituições, como já o fazia a de Filadélfia, de 1787, o modo de alterar a Lei fundamental, sem romper com ela, mas de acordo com ela.

17 V. Ferraz Anna Cândida da Cunha, Processos informais de mudança da Constituiçāo, Limonad, São Paulo, 1986.

18 V. Cattaneo, ob. cit., p. 15 e s. 
Ora, este Poder de alterar a Constituição obedecendo a preceitos que esta própria estabelece é, também, para a doutrina, clássica, um Poder Constituinte.

Qual é, porém, a natureza deste Poder Constituinte que pode editar normas de força constitucional, mas de acordo com a Constituição?

Não pode ser ele visto como o próprio Poder Constituinte que origina a Constituição. Não apresenta os caracteres deste. Não é nem inicial, nem ilimitado, nem incondicionado. Ao contrário, é derivado da Constituição, limitado e condicionado pela Constituição portanto, pelo Poder originário que a estabeleceu.

É verdade que disso discordam alguns autores, como Duguit, Laferrière, Vedel etc., para os quais o Poder de Revisão é o próprio Poder Constituinte originário que permanece presente na sua obra, a Constituição. Conseqüentemente consideram as regras de procedimento e limitação meras recomendações sem força jurídica. Mas são minoria ${ }^{19}$.

A maioria entende existir um Poder Constituinte constituído, o qual pode alterar a Constituição - portanto, as normas que edita tem o mesmo valor das que foram postas pelo Poder originário - mas de acordo com o procedimento fixado e as limitações estabelecidas na Constituição.

\section{A visão cética: um procedimento agravado}

Haverá mesmo esse Poder Constituinte constituído?

Certamente não como órgão institucionalizado. Nenhuma Constituição o prevê.

Sem dúvida, várias Constituições procuram por o Poder de Revisão em mãos de órgão distinto do incumbido de legislar. Disto o melhor exemplo é a Constituição Americana, cujo art. $V$ prevê a reunião de um Convenção para fazê-lo. Ou buscam, pelo menos, renovar inteiramente a composição da Casa legislativa, a fim de dar "mandato" constituinte aos seus membros. É o que previa a Carta Imperial de 1824, no art. 176.

Entretanto, o mais das vezes é o próprio Legislativo que pode alterar a Constituição, embora para tanto se reclame um procedimento mais complexo e oneroso do que o previsto para a edição da legislação comum. Comum é a exigência de maioria qualificada, $2 / 3$ dos votos ou $3 / 5$, em vários turnos seguidos, como é o caso da Lei Magna de 1988 (art. 60, $\S 2^{\circ}$ ).

Ora, pelo menos nestes casos, deve-se entender que a alteração da Constituição não é obra de um Poder específico, mas sim do Legislativo, mediante um procedimento agravado.

No direito brasileiro em vigor, vem em abono deste juízo o fato de que o art. 59 da Constituição inclui a elaboração de Emendas à Constituição no processo legislativo, no mesmo pé que as leis complementares, as leis ordinárias, as leis delegadas, as medidas provisórias, os decretos legislativos e as resoluções... 


\section{b) As limitações à alteração constitucional}

\section{A limitação da alterabilidade}

Ao disciplinar a alteração da Constituição forçosamente estabelece regras de procedimento a tanto aplicáveis. Serão estas - é um primeiro problema - alteráveis?

Por outro lado, ela exclui tal modificação, em razão do tempo, das circunstâncias, ou da matéria. Traça, pois, limites para essa alteração.

Todos esses pontos reclamam estudo.

\section{A modificação das próprias regras de modificação}

Com relação a estas regras de procedimento, coloca-se um problema de lógica.

Para certos autores que seguem Alf Ross ${ }^{20}$, o processo de alteração da Constituição não poderia ser alterado, mesmo com a observância das normas que disciplinam a mudança das normas constitucionais. É a questão dita da inalterabilidade das normas auto-referentes.

Pretende esse filósofo dinamarquês que, em termos de lógica jurídica, a alteração das regras de alteração recundaria num absurdo, pois, a conclusão contradiria uma das premissas do silogismo. Trata-se de uma argumentação extremamente abstrata que não se pode aqui resumir.

Cabe observar, todavia, que a tese de Ross foi várias vezes refutada por outros filósofos do direito. Assim o foi por Eugenio Bulygin, por Hart etc.

Em termos pragmáticos, porém, essa vedação jamais foi embaraço. Na França, em 1958, foram alteradas as normas que presidiam à revisão na Constituição de 1946. No Brasil, isto se deu, por exemplo, pela Emenda Constitucional n ${ }^{\circ} 22 / 82$ à Carta anterior. E certamente também o foi, num contexto político de "abertura" pela Emenda no $26 / 85$ que ensejou a elaboração da Constituição em vigor.

\section{Os limites temporais}

Passa-se agora às limitações propriamente ditas.

A primeira espécie delas é a da limitação temporal. A constituição proíbe a sua alteração por um determinado prazo. A Carta do Império, no art. 174, vedava por quatro anos o desencadear do processo de alteração.

Isto visa, sobretudo, a dar tempo para que as normas editadas possam ganhar efetividade. Ou para que ganhem aplicabilidade por meio das normas ordinárias de complementação.

20 V. sobre tudo isto, Klein, ob. cit., p. 123 e s. 


\section{Os limites circunstanciais}

Outro tipo de limitação é o que, em certas circunstâncias de anormalidade política, proíbe a modificação.

Pressupõe-se que as alterações à Constituição - exatamente pela importância e dignidade desta - não devam ser decididas senão depois de uma ponderação objetiva e isenta de pressão de acontecimentos extraordinários, de ordem política. Tais eventos, anormais, podem precipitar soluções mal avisadas.

No direito francês, isto aparece na proibição de alterar a Constituição, estando o território nacional ocupado, no todo ou em parte, por inimigos (art. 89). É a lembrança de 1940, quando a Terceira República foi extinta, quando parte do território francês estava ocupado por tropas alemãs.

Claro está que essa limitação importa em vedar alterações constitucionais que sirvam para a superação de crises graves.

\section{c) As limitações materiais}

\section{O núcleo básico}

Não é infreqüente estabelecerem as Constituições proibições de alteração quanto a certos pontos, matérias ou princípios. Estabelecem, em consequiencia, o chamado cerne "intangível" da Lei Magna.

A idéia é antiga. Já a pôs em execução a Constituição Americana ao proibir, no art. V, a supressão da igual representação dos Estados do Senado. Hoje ainda, por exemplo, a Constituição francesa de 1958 veda a abolição da forma republicana de governo (art. 89).

Traduziriam estas vedações a garantia do núcleo fundamental da Lei Magna, ou seja, na linguagem de Carl Schmitt, da Constituição positiva. Tal núcleo consistiria exatamente no "modo e forma da unidade política". Seria ele a expressão da decisão política do Poder Constituinte. Por isso, tal núcleo existiria em toda Constituição, mesmo quando esta não o explicitasse.

Autores há - como Sousa Sampaio - que apontam matérias inerentes a esse núcleo, como a definição de soberano, a declaração dos direitos e garantias fundamentais etc ${ }^{21}$.

\section{O valor das limitações materiais}

O valor destas tem sido de há muito discutida. Na verdade, são elas, dentre todas, as mais importantes, pois as temporais ou circunstanciais retardam a mudança, enquanto as materiais a impedem. 
Identificam-se três correntes quanto a esta questão.

A primeira é evidentemente a dos que aceitam plenamente a sua validade. Apoiam-se na idéia de que o Poder de Revisão é um poder constituído, entendem dever este sempre respeitar a regra de competência - portanto, a limitação.

A Segunda toma posição diametralmente oposta. Para ela, tal limitação é inválida. Ela o é, porque usurpa das gerações futuras a liberdade, isto é, o poder de determinar "o modo e forma da unidade política". Citam os seus partidários o célebre art. 28 da Declaração de 1793: "Um povo tem sempre o direito de rever, de reformar e de mudar a Constituição. Uma geração não pode sujeitar a suas leis as gerações futuras."

A terceira é mais moderada. Contesta o caráter absoluto das proibições. Admite que podem estas ser suprimidas pelo Poder de Revisão, de modo que, após isto, mudanças a ela contrárias poderiam ser feitas. É a tese da revisão de "duplo grau", a que adere, embora com restrições, Jorge Miranda ${ }^{22}$.

É isto - objetam os seguidores da primeira tese - uma fraude à Constituição. E recebem a réplica de que, sendo as proibições - as "cláusulas pétreas", como se costuma dizer no Brasil - um mero agravamento da rigidez, inexiste tal vício e, ao invés, cumpre-se o almejado pela Carta.

\section{A inconveniência da imutabilidade}

A última tese tem por si uma importante razão, de caráter político.

O bloqueio da mudança é em si mesmo contraproducente, politicamente falando. Visa a dar estabilidade à ordem constitucional, mas, por um efeito perverso, contribui para a sua desestabilização.

Com efeito, ela impede a adaptação das regras a novas exigências, fruto de novos tempos. Pode disto resultar a indesejável ruptura, para que de novo se manifeste o Poder Constituinte.

Evidentemente o problema se agrava, quando a Constituição é analítica. Esta não só torna questão constitucional mudanças que não tocam a organização básica do Estado, mas pode levar à crise se tomadas como absolutas.

Observe-se ademais que, na prática, pelo menos de Portugal, as regras de proibição não têm sido consideradas imutáveis. Na verdade, a terceira revisão da Constituição, feita em 1989, não hesitou em modificar regras constantes do rol das que fixavam, no texto primitivo, de 1976, limitações materiais à sua revisão ${ }^{23}$.

22 V. Miranda Jorge, Manual de Direito Constitucional, $3^{2}$ ed., Coimbra Ed., Coimbra, 1991, p. 175 e s.

23 De fato, modificou ela - e radicalmente - o teor das alíneas "f" e " $g$ " do art. $290^{\circ}$ do texto de 1976 e suprimiu o que constava da alínea "j". É o que se pode ver do art. $288^{\circ}$ da Revisão de 1989 (hoje renumerados pela $4^{a}$ Revisão, em 1997). 


\section{A inclusão da Emenda no processo legislativo}

Comece-se por observar que, no art. 59, ao referir-se ao processo legislativo, a Constituição inclui no inciso I, as Emendas, enunciando a seguir os demais atos normativos, lei complementar, lei ordinária, lei delegada, medidas provisórias, decretos legislativos e até resoluções.

Disto pode-se depreender que, para ela, o poder de emendar não tem natureza distinta do de legislar. E reforça esta visão o fato de que a elaboração da emenda se dá no campo do Congresso Nacional, como a da lei, não sendo necessário, por exemplo, o referendo popular.

Neste quadro, a emenda não passaria de ato normativo que difere dos demais por um procedimento especial, agravado, como ocorre com a lei complementar em comparação com a lei ordinária.

\section{Emenda e revisão}

Note-se, ademais, que, no corpo da Constituição, não se fala senão em Emenda, mas no art. $3^{\circ}$ do Ato das Disposições Constitucionais Transitórias prevê-se "revisão". Ou melhor, uma revisão prevista para cinco anos depois da entrada em vigor da Lei Maior, que já se realizou ${ }^{24}$.

$\mathrm{Na}$ verdade, revisão neste último texto é claramente um procedimento simplificado de alteração constitucional. Conforme esse artigo, pela revisão seria aprovadas mudanças na Carta pelo voto da maioria absoluta dos membros das Casas do Congresso reunidas. Com isto, excepcionava-se à exigência do voto de $3 / 5$ dos membros de cada Câmara, em dois turnos, como vem no art. $60, \S 2^{\circ}$ da Constituição.

Seguindo este procedimento, adotaram-se, conforme todos sabem, seis Emendas de Revisão à Carta Magna. Corrobora, portanto, a prática a assertiva acima, de que, na Lei Maior vigente, revisão nada mais é, ou foi, senão um procedimento simplificado, não o reexame total do texto.

Mas um procedimento previsto em caráter excepcional e para uma oportunidade.

\section{a) Aspectos formais}

\section{A iniciativa}

A proposição de Emendas no texto vigente é, segundo dispõe o art. 60, I, deferida a "um terço, no mínimo, dos membros da Câmara dos Deputados ou do Senado

24 Completamente infundada, e rejeitada pelo Supremo Tribunal Federal bem como pela experiência, a tese de que esta revisão estaria vinculada à aprovação, no plebiscito previsto no art. $2^{\circ}$ do ADCT, da opção pela monarquia constitucional ou pelo parlamentarismo. 
Federal". Trata-se, pois, de ato coletivo. Diferentemente do que se dá com a lei ordinária, um parlamentar isolado não pode propor a adoção de mudança na Constituição. Claro está que, teoricamente, isto visa a dar maior peso a uma tal proposta, que somente poderia provir de um número significativo de deputados, ou senadores (nunca de deputados e senadores somados). Entretanto, a prática do "apoiamento" ${ }^{25}$, tolerada embora inconstitucional, esvaziou a exigência.

Também é ela atribuída (art. 60, II) ao Presidente da República, como já vinha do direito imediatamente anterior. Neste caso, é obviamente ato simples.

Ressuscitou, porém, a Constituição (art. 60, III) a iniciativa por parte de Assembléias Legislativas estaduais. Esta, que fora prevista nas Leis Magnas de 1891, 1934 e 1946, desapareceu com a Carta de 1967, mas foi restabelecida pela vigente. Realmente, a Emenda poderá ser proposta "por mais da metade das Assembléias Legislativas" estaduais - e penso que entre estas se poderia incluir a Assembléia do Distrito Federal - desde que estas se manifestem por maioria - maioria relativa, diz o texto. (Curioso seria que estas não se manifestassem por maioria...). Esta previsão é uma inutilidade. Bem mais fácil é encontrar, ainda mais com o apoiamento, um terço de deputados ou de senadores que apresentem a proposição.

\section{Renovação de iniciativa}

Quanto ao caso de proposta que houver sido rejeitada ou havida por prejudicada, não poderá ela ser renovada na mesma sessão legislativa. O objetivo desta regra é aliviar a carga de trabalho do Congresso Nacional. Contudo, é facilmente contornável, pois bastará alterar em parte o texto, para que deva ser ela, ou venha a ser ela considerada como nova...

\section{O procedimento}

No tocante a este aspecto, a Constituição apenas regula a fase deliberativa. Estabelece que o texto proposto deverá ser discutido e votado em dois turnos em cada Casa do Congresso, separadamente. Para ser aprovado, deverá obter, no mínimo, em cada votação, $3 / 5$ dos votos dos membros da Casa. Como se sabe, o texto anterior a este respeito variou, ora exigindo a maioria absoluta, ora a maioria de 3/3.

Note-se que de modo algum se pode aplicar à proposta de Emenda a regra estabelecida, para projetos de lei, no art. 65 da Lei Magna. Neste, com efeito, uma das Casas - aquela em que não houver sido depositado o projeto - atua como

25 Na prática parlamentar brasileira, o apoiamento consiste numa assinatura de favor pela qual um deputado ou senador apoia a iniciativa de outro, sem se comprometer em votar a favor dela, mas apenas para suprir uma exigência formal, como é o caso acima examinado. É evidente que isto é uma fraude à norma constitucional, contudo é admitida sem impugnação nem contestação nos trabalhos do Congresso Nacional. 
revisora. Assim, se aprovar o texto com modificações, este voltará à primeira Casa que poderá ou adotar essas alterações, ou rejeitá-las, e sem mais o projeto subirá à sanção. Em relação a Emenda constitucional, texto igual deverá ser aprovado, em cada turno, pelas duas Casas, para que se cumpra a exigência constitucional.

\section{Promulgação}

A Emenda não depende de sanção, nem é suscetível de veto. Por isso, uma vez aprovada pela Segunda Casa a conhecê-la, estará perfeita e acabada e será então promulgada. Esta promulgação há de ser feita, em conjunto, pelas Mesas das Casas do Congresso Nacional (art. 60, § $3^{\circ}$ ).

Receberá ela então um número de ordem.

\section{Os limites circunstanciais}

Pode-se incluir entre os aspectos formais a proibição de discutir e votar, "na vigência de intervenção federal, de estado de defesa ou de estado de sítio", proposta de Emenda.

A razão disto é que as medidas apontadas importam numa anormalidade política. Assim, presumem um ambiente desfavorável à apreciação objetiva da proposta. No tocante ao estado de sítio e ao estado de defesa (modalidade atenuada daquele), ocorre uma suspensão de garantias - portanto uma restrição ao exercício de direitos fundamentais - que não propícia a tal apreciação. Por isso, já constava do direito anterior a vedação, estando eles em vigor, mas não se levava em conta a intervenção federal.

Vale observar, no entanto, que, na experiência brasileira, a solução de graves crises veio de alterações constitucionais. É o que se passou em $1961^{26}$, quando, para evitar uma guerra civil iminente, foi adotado o sistema parlamentar de governo. Nesse período, para evitar que o estado de sítio impedisse a mudança constitucional em que se via a saída para o problema, foram adotadas, na prática, as medidas previstas para o caso do estado de sítio. Fugiu-se assim à legalidade para propiciar uma alteração não impugnável por inconstitucionalidade.

\section{b) Os limites materiais}

\section{8. $O$ art. $60, \S 4^{\circ}$ da Constituição}

Convém recordar art. $60, \S 4^{\circ}$ da Lei Magna de 1988. Estabelece ele:

26 Havendo o Jânio Quadros renunciado à Presidência da República, em 25 de agosto de 1961, parte das Forças Armadas veio a opor-se à posse do Vice Presidente João Goulart, que contava com o apoio do $3^{\circ}$ Exército, sediado no Rio Grande do Sul. A saída política foi a ação da Emenda $n^{\circ} 4 / 61$ (à Constituição de 1946), que instaurou o parlamentarismo (a qual foi revogada em janeiro de 1963, pela Emenda $n^{\circ} 5 / 63$ ). 
“ $\S 4^{\circ}$ - Não será objeto de deliberação a proposta de emenda tendente a abolir: I - - a forma federativa do Estado;

II - o voto direto, secreto, universal e periódico;

III - a separação dos Poderes;

IV - os direitos e garantias individuais."

Merece este texto um exame detido e cuidadoso.

\section{Que significa "tendente a abolir"?}

O primeiro ponto a estudar é o próprio enunciado do parágrafo. Concerne este a propostas tendentes a abolir determinados princípios.

O elemento fundamental nesse texto é o termo abolir. Abolir - não é preciso consultar o dicionário - significa extinguir, eliminar, por fim a ... claro fica, portanto, que a proibição visa a impedir a eliminaçāo dos pontos enunciados nos diversos incisos seguintes. Tal interpretação, ademais, coincide nitidamente com a intenção da norma, que é preservar certos princípios.

É verdade que o texto fala em "tendente" 27 a abolir. Mas disto não se infere interpretação diferente. Com efeito, "tendente a abolir" não significa mais que "se aproxime" de abolir, o que importaria, no máximo, em apontar um critério de interpretação. Isto é, em advertir o intérprete que, ao aferir se uma proposta colide com a proibição, proscreva a que, sem abolir o princípio, possa aproximativamente fazê-lo, por exemplo esvaziando-o. De modo algum, leva a uma petrificação granítica de tudo que abrangem os incisos enumerados no texto.

Resulta disto que estes princípios, desde que não sejam eliminados, podem ter o seu regime de aplicação alterado, sem que se infrinja a proibição.

$\mathrm{Na}$ verdade, esta posição tem por si a experiência. A proibição de sequer deliberar sobre propostas tendentes a abolir a "forma federativa" não impediu, sob a Constituição de 1946 (que a enunciava - art. $217, \S 6^{\circ}$ ), reforma tributária que certamente alterava a estrutura da federação brasileira, pois afetava concretamente a autonomia dos Estados.

\section{A forma federativa}

Data esta proibição da Constituição de 1891 e sempre esteve em nosso direito constitucional, com exceção do período de vigência (teórica) da Carta de 1937. Veda a transformação do Estado brasileiro em Estado unitário, mesmo descentralizado, por exemplo.

Até ontem, desconheciam-se propostas de supressão da Federação, Hoje, invocando principalmente o custo de manutenção das máquinas governamentais e admi-

27 Há céticos que sugerem haver sido empregada a locução "tendente a abolir" por se desconhecer o subjuntivo de abolir... 
nistrativas estaduais, e mesmo municipais, há quem o pleiteie ${ }^{28}$. Será, porém, que o peso político que adviria de uma centralização ainda maior do que a que vivemos (pois o nosso federalismo já acentua desmesuradamente a força do poder central), não seria um mal pior?

\section{O voto direto, secreto, universal e periódico}

Não constava esta limitação do direito anterior. Trata-se de expressão do princípio democrático. No fundo, é a democracia que se pretende resguardar por meio desta vedação.

\section{A separação dos Poderes}

Também está aqui uma inovação da Lei Magna de 1988.

Que se há de compreender por separação dos Poderes neste inciso?

Manda o bom senso excluir a hipótese de referir-se à doutrina clássica, de Montesquieu. Uma Constituição que admite medida provisória colide frontalmente com essa teoria.

Parece ela apenas significar a proibição de suprimir qualquer dos três Poderes “clássicos" - Legislativo, Executivo e Judiciário.

Importaria também em garantir-lhes a independência recíproca?

Sim, mas em termos, porque, indo às últimas consequiências, separação dos Poderes exclui sistema parlamentar de governo, o qual se baseia numa interdependência jurídico-político entre Legislativo e Executivo, e vice-versa. Ora, o art. $2^{\circ}$ do A.D.C.T. o admitia como opção.

\section{Os direitos e garantias individuais}

Não explicitativa o direito anterior esta limitação. Já havia, porém, quem a sustentasse implícita no nosso direito ${ }^{29}$.

Provoca a interpretação deste inciso interessantes questões, até agora pouco ou mal examinadas.

Em primeiro lugar, ao pé da letra, o texto, cuja óbvia intenção é proteger os direitos fundamentais, exclui da garantia os direitos sociais (e nem se fale dos direitos de solidariedade).

Parece-me isto absurdo e por isso sempre sustentei que o legislador disse menos do que queria e assim os direitos sociais estão incluídos na proibição. Afinal, na interpretação - ja ensinavam os romanos - há de prevalecer o espírito, não a letra.

28 Tem aparecido como apóstolo disto, entre outros, o Prof. Ives Gandra da Silva Martins.

29 Sousa Sampaio, ob. cit., p. 93. 
O segundo é se os direitos protegidos são apenas os mencionados no Título II da Constituição "Dos direitos e garantias individuais?"

Dizer sim à pergunta consistiria num formalismo e importaria em excluir da proteção direitos fundamentais que a Lei Magna previu, noutros Títulos, por exemplo, entre as limitações do poder de tributar. Na verdade, o Supremo Tribunal Federal já decidiu que estão cobertos pela proteção estes direitos fundamentais que não estão consagrados no Título II referido. E sua posição é corretíssima.

Isto, contudo, leva a uma indagação delicada: Que são direitos fundamentais?

Ora, partindo-se de uma conceituação de direito fundamental pelo conteúdo, forçosamente se chega a duvidar que, por exemplo, todos os direitos enumerados no art. $5^{\circ}$ - como direito a certidões sejam fundamentais... E aí...

Por outro lado, o famoso art. $5^{\circ}, \S 2^{\circ}$ da Constituição dá status de direitos fundamentais a direitos decorrentes de tratados de que o Brasil seja parte. Isto significaria não poderem ser estes tratados denunciados? Ou haverem-se incorporado tais direitos ao nosso ordenamento de modo definitivo, mesmo se o tratado é denunciado?

Estão nas duas últimas questões problemas de altíssima indagação a desafiar os doutos. Destes é que se espera a resposta.

\section{Haverá outras limitações, implícitas?}

Não descabe considerar esta outra pergunta, por mais delicada que seja.

Pode-se sustentar, à guisa de resposta, que numa constituição que explicita limitações, o que não foi enumerado pode ser mudado sem obstáculos jurídicos. Realmente, pode-se presumir que o legislador constituinte escolheu entre o que merecia a proteção e pôs de parte certas matérias. É a tese mais cautelosa.

Entretanto, na linha de Carl Schmitt, não descabe pretender que, derivando a imutabilidade, da "decisão sobre o modo e a forma de unidade política", o que se inclui neste campo goza da proteção, ainda que não tenha sido enunciado como a merecendo.

Põe-se o problema, por exemplo, no caso da república, em face da atual Constituição. A forma de governo republicana tradicionalmente gozava da mesma proteção de a forma de Estado federativa. O texto vigente não enunciou, tendo em vista o plebiscito previsto no art. $2^{\circ}$ do A.D.C.T. Este, de fato, previa a opção pelo povo brasileiro entre república e monarquia constitucional ${ }^{30}$.

Entretanto, havendo este povo optado pela república, não será esta uma decisão, e capital, sobre o "modo e forma da unidade política"? Não estará, por isto, resguardada contra outras tentativas monarquistas?

30 Mas isto nunca passou de um artifício para propiciar o plebiscito entre parlamentarismo e presidencialismo. 
a) Aspectos gerais

\section{A lógica da supremacia da Constituição}

No atual estágio de evolução do direito, não mais se discute a imperatividade da Constituição. Desta decorre ser a observância de suas regras condição de validade - a condição de constitucionalidade — de todo e qualquer ato praticado por Poder que ela se origine - como o de Revisão (se é Poder...).

Também, não se contesta que essa imperatividade importa num instrumento que a efetive contra tudo e todos, ou seja, um controle de constitucionalidade exercido por órgão que tenha o poder de proscrever os atos que ferem a Constituição. Demonstração disto é a importância que vem assumindo, pelo mundo afora, a chamada justiça constitucional.

\section{O controle das alterações constitucionais}

Não há razão para excluir do caso geral acima as alterações constitucionais evidentemente postas de parte as estabelecidas pelo Poder originário.

Com efeito, se obra de um Poder, o Poder de revisão, é este um Poder constituído, portanto, subordinado à Constituição e condicionado por ela. Se não passa a alteração de um procedimento legislativo agravado, com mais razão ainda cabe o controle. Por isto, é unânime a doutrina a admitir esse controle de constitucionalidade sobre alterações, emendas à Lei Magna. E tanto no Brasil ${ }^{31}$, como no estrangeiro ${ }^{32}$.

\section{Controle sobre a forma e sobre o fundo}

Este controle, nem seria preciso dizê-lo, incide tanto sobre a forma como sobre o fundo em relação às alterações.

Tanto deve ele conferir se o procedimento pelo qual foi ela adotada seguiu rigorosamente os preceitos constitucionais, como se o seu conteúdo não colide com as limitações materiais, explícitas ou implícitas que contém a Lei Maior.

31 V. por todos Zeno Veloso, Controle jurisdicional de constitucionalidade, CEJUP, Belém, 1999, p. 133.

32 Antes, por exemplo, da ratificação do Tratado de Maastricht, o Conselho Constitucional francês foi chamado a manifestar-se. 


\section{Os meios de controle}

É hoje bastante complexo o sistema de controle de constitucionalidade no Brasil. Afora o mecanismo tradicional, que já vem da Primeira República - o controle desconcentrado, concreto, incidental - prevê a Lei Magna o controle concentrado, em mãos do Supremo Tribunal Federal, de caráter abstrato e principal, seja por meio da ação direta de inconstitucionalidade, seja por meio da ação direta de constitucionalidade, para não se falar na ação direta de inconstitucionalidade por omissão. ${ }^{33}$.

\section{O controle por via incidental}

Admitido caber o controle de constitucionalidade sobre Emendas, nenhuma razão há para que este não se possa dar pelo caminho do controle incidental. Mas desde que a norma editada pela Emenda seja auto-aplicável.

Realmente, no caso das normas que não reclamam complementação ou regulamentação, direito individual pode ser afetado por regra editada em Emenda, ou ser posta afirmado ou negado, hipóteses em que a solução de eventual litígio passa pela determinação da constitucionalidade ou inconstitucionalidade. Cai-se aqui no terreno comum. Qualquer juiz pode declarar a inconstitucionalidade, formal ou material, de regra editada por Emenda, devendo, todavia, a questão subir, pelo jogo dos recursos e em última análise por força do extraordinário, até o Supremo Tribunal Federal.

É este, então, que dirá a última palavra.

Não se olvide que, neste caso, a declaração da inconstitucionalidade se dá in casu e inter partes. Apenas, será suspensa, em caráter geral, a execução da Emenda se o decidir o Senado Federal, nos termos do art. 52, X da Lei Magna.

\section{0. $O$ controle abstrato}

Não faz dúvida igualmente caber o controle abstrato, seja por ação de inconstitucionalidade, seja por ação de constitucionalidade.

A expressão "lei ou ato normativo federal" deve ser interpretada, como sempre tem sido, de modo amplo. Ou seja, abrangendo todas as espécies normativas gerais editadas pelo Poder federal, que é, de um ângulo, o Poder nacional.

Neste caso, por força da jurisprudência do próprio Supremo Tribunal Federal, a decretação da inconstitucionalidade tem efeito erga omnes, independe de suspensão da execução pelo Senado Federal.

33 Só não prevê a Constituição o que melhor atenderia às condições atuais decorrentes de seu caráter enxundioso e analítico - o controle preventivo que evitaria a multiplicação dos choques entre Executivo e Legislativo, de um lado, Judiciário, de outro, acerca da constitucionalidade das leis e outras medidas, choques estes daninhos para o regime. 
É isto confirmado pela lei $\mathrm{n}^{\circ} 9.868$, de 1999 , que veio regulamentá-la (art. 28, parágrafo único) ${ }^{34}$. Nesta, ademais, foi dada às decisões da Suprema Corte eficácia erga omnes e efeito vinculante. Isto mesmo nas decisões em ação de inconstitucionalidade, estendendo-se o preceituado para as ações de constitucionalidade (Constituição, art. $102, \S 2^{\circ}$ ).

\section{O caso da argüição de descumprimento de preceito fundamental}

A Constituição previu, no art. $102, \S 1^{\circ}$ uma "argüição de descumprimento de preceito fundamental”, cujo alcance se constitui num mistério insondável para os intérpretes.

Por força da lei ${ }^{\circ} 9.992$, de 1999 , foi ela regulamentada. Do texto depreende-se constituir no fundo uma avocatória, prevista como podendo colher qualquer processo judicial, em qualquer instância, visando a solucionar conflito acerca da constitucionalidade de ato normativo ${ }^{35}$.

Muito se assemelha, na sua estrutura à ação direta de inconstitucionalidade. Igualmente, nos seus efeitos, pois, a decisão tomada tem eficácia erga omnes e efeito vinculante.

Certamente esta argüição pode versar a constitucionalidade de Emenda à Constituição.

\section{2. $O$ caso da ação de inconstitucionalidade por omissão}

Versando omissões constitucionais, esta ação não serve para o controle de constitucionalidade das Emendas.

Evidentemente, cabe em relação a normas de Emenda. Não há por que negá-lo. Com efeito, a implementação de regras que vierem editadas por Emenda pode reclamar providências, quer normativas, quer administrativas, a respeito das quais eventualmente se omita o Poder competente. Ora, isto se enquadra perfeitamente no que preceitua o art. $103, \S 2^{\circ}$ da Constituição em vigor.

\section{A nulidade da norma inconstitucional}

Pertence à doutrina clássica a tese da nulidade do ato inconstitucional. É esta a que prevalece na jurisprudência do Supremo Tribunal Federal que tem até acórdãos em que essa posição é expressa ${ }^{36}$. É verdade que, hoje, em decorrência das leis $n^{\circ}$

34 V. sobre tal lei meu artigo "O sistema constitucional brasileiro e as recentes inovações no controle de constitucionalidade", em Revista de Direito Administrativo, 220/1.

35 Id., ibid.

36 Embora ele próprio às vezes disso se esqueça, por exemplo mantendo em vigor, e ainda hoje aplicando, a Súmula n 5 . 
9.868 e 9.992 , de 1999 , tal nulidade, embora seja a regra, pode ser excepcionada em casos especiais ${ }^{37}$.

Sempre houve, todavia, quem, como Kelsen ${ }^{38}$, que tenha contestado essa lição. Ela seguramente não está presente na orientação de Cortes constitucionais, como a alemã. Não é aqui e agora que se deva discuti-la.

Cumpre observar que, acerca de norma editada por Emenda, que, portanto, muda a Constituição, difícil, muito difícil é aceitar não seja ela nula e írrita.

\section{Conclusão}

\section{Resumo das observações principais}

Cabe agora concluir este trabalho, sem dúvida, sintético e simplificador, sublinhando as suas idéias mais importantes. Estas põem em discussão, e de modo propositalmente agressivo, algumas das "verdades" a que reverenciam, sem exame crítico, muitos juristas. Ou seja:

A doutrina clássica do Poder Constituinte toma um modelo ideal e irreal como paradigma. Sieyès certamente não quis formular uma doutrina jurídica ${ }^{39}$. A experiência desde o século XVIII já demonstrou não se estabelecerem as Constituições, como não foram estabelecidas - senão em práticas muito diferentes.

Por outro lado, o chamado Poder Constituinte de Revisão, ou derivado, nada tem de um verdadeiro Poder. Deve ser visto mais realisticamente como um procedimento agravado, pelo qual o Poder Legislativo - melhor se diria Poder representativo - altera a Constituição observando os padrões por esta estipulados.

Claro está que isto não infirma nem a Constituição - é a lei suprema e o reconhecimento de uma lei como suprema convém à boa ordem política - nem as limitações ao Poder de Revisão, pois estas definem o que para uma geração pareceu nuclear o Estado e assim merece das gerações subsequientes um respeito especial.

Não há, portanto, limitações que possam ser vistas como imutáveis. As ditas "cláusulas pétreas" são apenas um caso de rigidez acentuada, podem ser suprimidas, embora não possam ser contraditadas, enquanto vigorem. Nessa supressão, inexiste qualquer fraude, em conseqüência.

Aplica-se isto evidentemente ao disposto no art. $60, \S 4^{\circ}$ da Constituição Brasileira. Este proibe - enfatize-se - abolir determinados princípios ou institutos, não veda seja o seu regime modificado. Alcança esta proibição, no que é mais importante, a de suprimir todos os direitos fundamentais, portanto também os direitos

37 V. o artigo já citado "O sistema constitucional brasileiro e as recentes inovações no controle de constitucionalidade."

38 Cf. Teoria Pura do Direito, Amado, Coimbra, trad. port., 2 ed., 1962, vol. II, p. 149 e s.

39 Sarcasticamente, Claude Klein refere-se à doutrina de Sieyès comme "mithe", "conte de fées" e diz que "o poder constituinte preenche evidentemente a função do mágico nas sociedades" primitivas (ob. cit., p. 194). 
sociais. Reclama ela, porém, a devida consideração sobre o que são verdadeiramente direitos fundamentais.

As alterações da Constituição - as Emendas - têm como condição de validade a constitucionalidade, como qualquer ato de quaisquer dos Poderes. Esta condição advém da supremacia da Constituição.

Para que se efetive esta supremacia, necessário é um controle de constitucionalidade. Deste não escapam as alterações à Constituição. Tal controle se há de fazer, por isso, quanto às próprias Emendas.

Abrange ele tanto os aspectos formais quanto os materiais. Importa o descompasso entre a Emenda e a Constituição, seja no que toca ao procedimento por que foi adotada, seja no que concerne ao confronto entre aquela e o núcleo essencial desta, em inconstitucionalidade. Esta não pode ter como consequiência senão a nulidade da Emenda.

No direito brasileiro, este controle se há de fazer por todos os meios por que a Constituição o admite em geral. Ou seja, pode efetuar-se incidentalmente a partir de qualquer litígio, ou, por ação direta de inconstitucionalidade, por ação direta de constitucionalidade e pela arguiição de descumprimento de preceito fundamental. 